\title{
Allosyndetic recombination between a chromosome of Aegilops umbellulata and wheat chromosomes
}

\author{
R. M. D. Koebner* and \\ K. W. Shepherd
}

\author{
Department of Agronomy, Waite Agricultural \\ Research Institute, Glen Osmond, South Australia \\ 5064.
}

\begin{abstract}
Allosyndetic recombination was induced between chromosome $1 \mathrm{U}$ of Aegilops umbellulata and wheat chromosomes by producing plants monosomic for this alien chromosome and homozygous for the mutant phlb allele, which permits homoeologous chromosome pairing. Recombinants were selected among the progeny of such plants by observing the disruption of the Glu-1-Gpi-1-Gli-1 linkage on both the alien chromosome as well as along wheat chromosomes $1 \mathrm{~B}$ and 1D. A frequency of $8 \cdot 0$ per cent recombination between the Gpi-U1 and the $G l i-U 1$ loci was estimated when chromosomes $1 \mathrm{U}$ and $1 \mathrm{~B}$ were simultaneously monosomic, whereas the rate of recombination was only $4 \cdot 6$ per cent when $1 \mathrm{~B}$ was present as a disome. Some double homoeologous recombinants between the three loci $G l u-1$, Gpi-1 and Gli-1 were also isolated. Control populations, where homoeologous pairing was suppressed by the presence of $P h 1$, did not produce any allosyndetic recombinants between Gpi-1 and Gli-1.
\end{abstract}

\section{INTRODUCTION}

It is widely recognised that scientific plant breeding tends to narrow the germplasm available within crop species. In addition some alien species are endemic in environments where their cultivated relatives cannot at present be grown. Thus the introgression of genetic variation from wild relatives has become an important goal in plant breeding. The wild relatives of wheat include species with one or more genomes in common with hexaploid bread wheat, and introgression from these is reasonably straightforward, requiring only hybridisation and selection for homologous recombinants. However, when the donor alien species is less closely related, it is necessary to interfere with meiotic pairing in order to induce allosyndesis between homoeologous chromosomes. Since homoeologous chromosome pairing in wheat is suppressed largely by the action of the Phl gene on chromosome 5B (Sears and Okamoto, 1958; Riley and Chapman, 1958), allosyndesis can be achieved by the deletion of $5 \mathrm{~B}$ (Riley and Kimber, 1966), the mutation of the Ph1 locus (Sears, 1977), or the suppression of the action of $P h 1$ by an alien genome (Riley et al., 1968).

\footnotetext{
* Present address: Plant Breeding Institute, Maris Lane, Trumpington, Cambridge CB2 2LQ.
}

The frequency of allosyndetic pairing between wheat and alien chromosomes in a Ph1 deficient background depends heavily on the evolutionary separation between the wheat and alien genomes. Thus it can reach quite high levels in some wheatAegilops spp. hybrids, while remaining rather low in the case of wheat-rye hybrids (Riley and Kimber, 1966). The Aegilops genus is known to contain an extensive reservoir of useful genetic variation, particularly with respect to genes for resistance to phytopathogens (Frauenstein et al., 1985; Valkoun et al., 1985), and some progress towards introgression from these species has already been made (Riley and Kimber, 1966; Riley et al., 1968; Dvořák, 1977; Ceoloni, 1984).

In this paper, recombination between chromosome 1U of Ae. umbellulata and wheat is described. Law (1984) has briefly reported work along similar lines, but the procedures employed and the details of the results achieved have not to date been published. Chromosome $1 \mathrm{U}$ has been disomically substituted for each of its wheat homoeologues (Shepherd, 1973; Chapman et al., 1975) and all three lines are fertile and show near-normal phenotypes, although the 1U(1D) substitution line is reported to be meiotically unstable at low temperatures (Chapman et al., 1975), and has a tendency to form shrivelled grain (Shepherd, 
unpubl.). The Aegilops chromosome carries both a Glu-1 and a Gli-1 locus (Shepherd, 1973; Lawrence and Shepherd, 1981) and a Gpi-1 locus (Chojecki and Gale, 1982), all of which code for gene products electrophoretically distinct from those of their wheat homoeoloci in cv. Chinese Spring. This alien chromosome is thus well suited to a study of induced allosyndetic recombination. The present work describes the production and identification of a substantial number of $p h 1 b$ induced intergeneric recombinants.

\section{MATERIALS AND METHODS}

\section{Plant materials}

(a) Disomic substitution lines $1 \mathrm{U}(1 \mathrm{~B})$ and $1 \mathrm{U}(1 \mathrm{D})$, having chromosome $1 \mathrm{U}$ of Ae. umbellulata replacing one wheat homoeologue in cv. Chinese Spring (Shepherd, 1973).

(b) ph1b mutant (Sears, 1977); two stocks used: (1) derivatives of Ac. 7876 with an unknown number of generations of self-fertilisation since the original isolation, and (2) Ac. 9821, a reselection from a $P h 1 b p h 1 b$ stock obtained from Prof. C. J. Driscoll. Accession numbers are those of Dr K. W. Shepherd (WARI, Adelaide, S. Australia).

(c) An accession of Ae. variabilis (Ac. 7069) obtained from Dr K. W. Shepherd.

\section{Electrophoresis}

SDS-PAGE was conducted on both unreduced and reduced extracts of mature endosperm to score for the Gli-1 and Glu-1 loci, respectively, following established methods (Singh and Shepherd, 1984, 1985). Reduced extracts were obtained by adding $10 \mu 1$ of 25 per cent $v / v 2$-mercaptoethanol to the remaining unreduced sample and incubating overnight at $4^{\circ} \mathrm{C}$ and for $2 \mathrm{~h}$ at $60^{\circ} \mathrm{C}$ on the day of the run.

Isoelectric focussing (IEF) and cellulose acetate electrophoresis (CAE) on Cellogel 250 (Chemetron) were used to score for Gpi-U1 and $G p i-B 1$, respectively. A small piece of mature endosperm was crushed and incubated overnight in $50 \mu \mathrm{l}$ of distilled water at $4^{\circ} \mathrm{C}$. Prior to electrophoresis, the samples were briefly centrifuged to obtain a clear supernatant. IEF gels were prepared by pouring a $0.5 \mathrm{~mm}$ thick gel $(5$ per cent I, 3 per cent C) containing 2 per cent Servalyt $3-10$ on a silanised glass plate. The gels were run at $1 \mathrm{~W} / \mathrm{cm}$ with the voltage limited to $2000 \mathrm{~V}$; the run consisted of $500 \mathrm{Vh}$ prefocussing, $1000 \mathrm{Vh}$ with the samples left on the gel approx. $1 \mathrm{~cm}$ from the cathode, and a further $1500 \mathrm{Vh}$ (total run $3500 \mathrm{Vh}$ ). The samples were prepared by saturating a $0 \cdot 4 \times$ $1.0 \mathrm{~cm}$ piece of Whatman $3 \mathrm{MM}$ chromatography paper with approx. $15 \mu l$ of supernatant. Staining was achieved by laying over the gel a strip of Cellogel 250 soaked in a mixture containing $2 \mathrm{ml}$ $0.3 \mathrm{M}$ Tris- $\mathrm{HCl} \mathrm{pH} 8,0.4 \mathrm{ml} 0.3 \mathrm{M} \mathrm{MgCl}_{2}, 0.4 \mathrm{ml}$ 0.2 per cent $\mathrm{w} / \mathrm{v}$ MTT, $0.4 \mathrm{ml} 0.05$ per cent $\mathrm{w} / \mathrm{v}$ PMS, $6 \mathrm{mg}$ D-fructose-6-phosphate, $4 \mathrm{mg} \beta$ NADP and $10 \mu \mathrm{l} \mathrm{G-6-PDH} \mathrm{(263} \mathrm{U/ml-Sigma).}$ After staining the overlays were fixed in 7 per cent glacial acetic acid, bathed for $20 \mathrm{~min}$ in 20 per cent $\mathrm{v} / \mathrm{v}$ glycerol and air-dried. For CAE, a strip of Cellogel 250 was equilibrated in electrode buffer $(0.025 \mathrm{M}$ Tris, $0.2 \mathrm{M}$ glycine) for $15 \mathrm{~min}$, and $2 \mu \mathrm{l}$ of sample was loaded onto each track with a Super$\mathrm{Z}$ Applicator (Helena Labs). Two rows of samples (each of 12 samples) were applied onto each $9 \times$ $10 \mathrm{~cm}$ strip. The gels were run at $350 \mathrm{~V}$ for $45 \mathrm{~min}$ at $4^{\circ} \mathrm{C}$, and stained, fixed and dried as described above.

\section{Cytology}

Standard Feulgen squashes of anthers at meiotic metaphase I were employed to analyse chromosome configurations in the pollen mother cells (pmcs) of selected plants.

\section{Production of populations containing wheat- Aegilops allosyndetic recombinants}

A scheme similar to that described in Koebner and Shepherd (1985) was used to obtain plants containing both one dose of wheat chromosome 1B (or 1D) and of chromosome $1 \mathrm{U}$ in a homozygous $\mathrm{ph} 1 \mathrm{~b}$ background. The mutant was used as the male parent in the cross to each substitution line to minimise transmission of unbalanced gametes, resulting from translocations accumulated in the ph $1 b$ stock (Koebner and Shepherd, 1985). In addition, for the cross involving the $1 \mathrm{~B}$ substitution, a selection of $p h 1 b$ from a heterozygote showing 21 regular bivalents at meiotic metaphase I was utilised to reduce further the extent of translocations within the male parent. The resulting $F_{1}$ plants were allowed to self-fertilise and both unreduced and reduced endosperm protein extracts of individual $F_{2}$ grains were analysed by SDS-PAGE to select individuals which presumably carried both $1 \mathrm{U}$ and the respective wheat chromosome on the basis of the presence of the appropriate protein bands. Approximately 20 such individuals from each $F_{2}$ population were grown and meiotically 
analysed to select for ph1b homozygosity, using a reduction in chiasma frequency as the major indicator (Koebner and Shepherd, 1985). Furthermore, as chromosome $1 \mathrm{U}$ could be easily recognised in meiotic chromosome preparations (fig. 1), any allosyndetic pairing which involved $1 \mathrm{U}$ could be identified and the occurrence of such allosyndetic pairing was a further criterion used to aid in the selection of ph1bph1b individuals.

One spike from each presumptive homozygous $p h 1 b$ plant was pollinated by $A e$. variabilis and the remaining spikes were left to self-fertilise to produce the populations to be screened for allosyndetic recombination. The wheat $\times$ Ae. variabilis hybrids were grown and analysed for the presence or absence of homoeologous pairing in pmcs at metaphase I. control populations, from plants of constitution $P h 1 b p h 1 b$ where homoeologous pairing was suppressed, were obtained from the $F_{2}$ generation of the cross of each substitution line $\times$ ph 1 bph $1 b$.
The progeny of plants having one dose of $1 \mathrm{U}$ and of constitution phlbphlb will be hereafter referred to as test $(\mathrm{T})$ populations, while those from $P h 1 b p h 1 b$ parents will be referred to as control (C) populations.

\section{Screening for wheat-Aegilops recombinants}

Initially, the Gli-1 and Glu-1 phenotype of each $\mathrm{T}$ and $\mathrm{C}$ seed was established. The genes controlling these two protein types are located on the short and long arms, respectively, of the group 1 chromosomes (reviewed by Payne et al, 1982). On the basis of the widespread evidence for the maintenance of gene synteny groups within wheat and its relatives (e.g., Hart et al., 1980), it was assumed that the same gene order existed on chromosome $1 \mathrm{U}$ as on $1 \mathrm{~B}$ and $1 \mathrm{D}$. Individuals with dissociated protein markers (e.g., Glu-B1 ${ }^{+} \mathrm{Gli}-\mathrm{B} 1^{-}$or Glu$\mathrm{U} 1^{-} \mathrm{Gli}-\mathrm{U} 1^{+}$) thus represent the products of either misdivision of the centromere or homoeologous

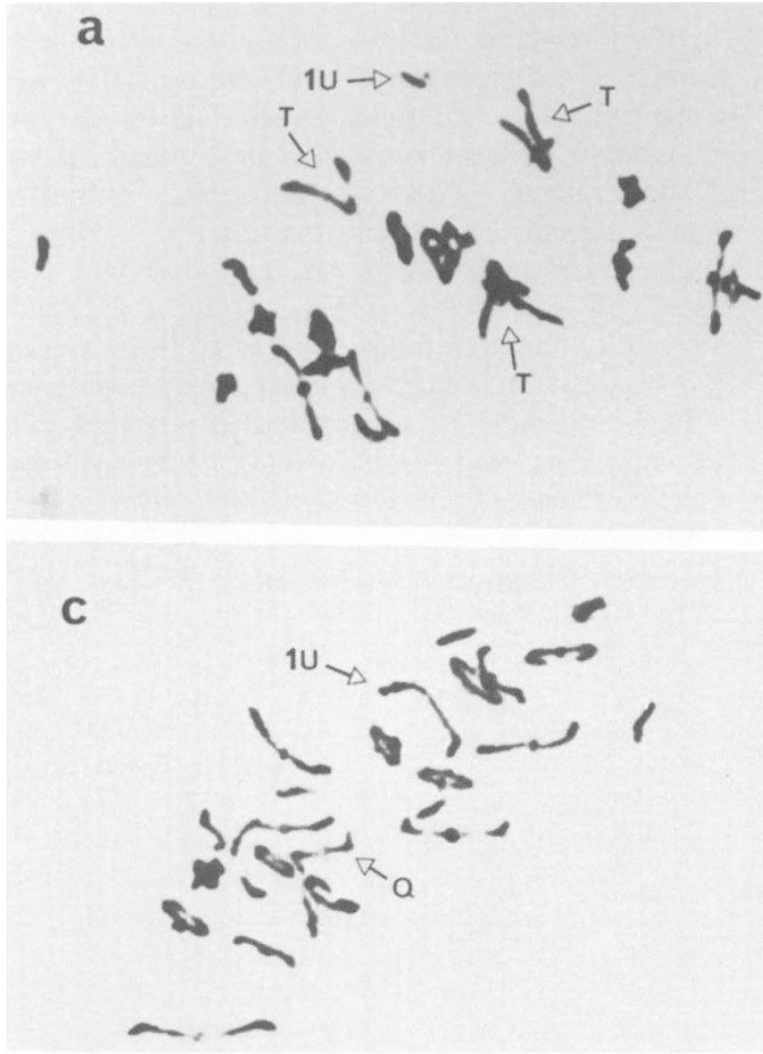

b
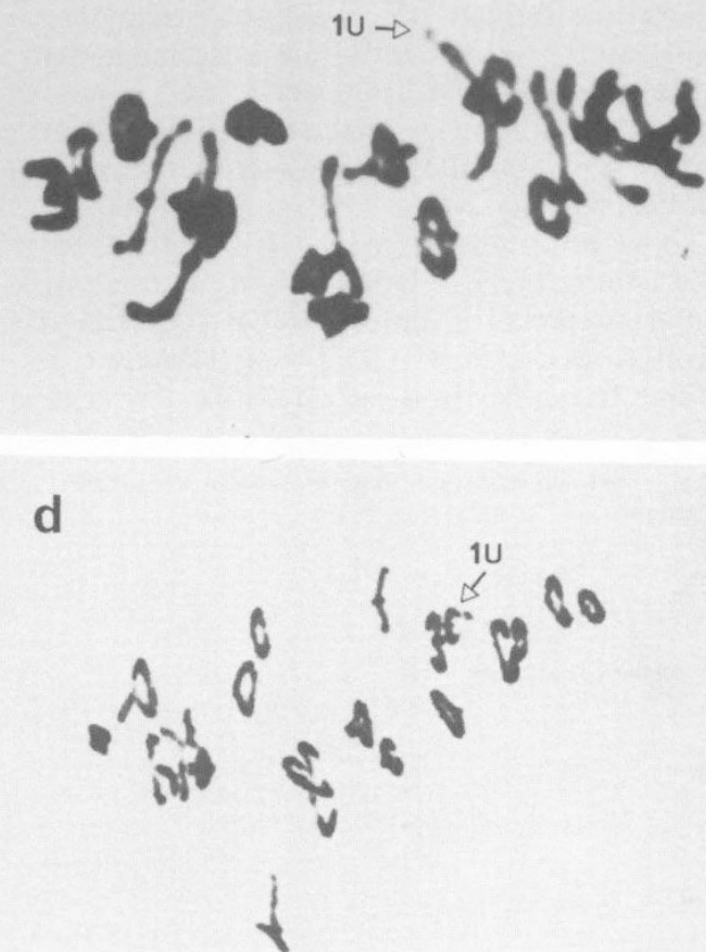

Figure 1 Chromosome configurations at metaphase I in pmcs of presumptive phlb homozygotes carrying one dose of chromosome $1 \mathrm{U}$, showing this chromosome (a) unpaired, and (b), (c), (d) paired. (a), (b) from cross involving substitution 1U(1B); (c), (d) from cross involving substitution 1U(1D). Pmc showing 1U unpaired: (a) Pmc showing $4^{\prime}+5^{[\prime \prime}+10^{(\prime \prime)}+3^{\prime \prime \prime}(\mathrm{T}=$ trivalent), Pmcs with $1 \mathrm{U}$ paired in a rod bivalent: (b) Pmc with probable configuration $1^{\prime}+8^{[\prime \prime}+13^{(\prime \prime)}$, (c) Pmc showing $4^{\prime}+8^{[\prime \prime}+9^{\prime \prime}+1^{\text {ir }}$ $(\mathrm{Q}=$ quadrivalent $)$, Pmc with $1 \mathrm{U}$ paired in a ring bivalent: (d) Pmc showing $3^{\prime}+4^{[\prime \prime}+16^{(\prime \prime \prime}$. 
recombination. Gpi-D1 is located interstitially between Gli-D1 and Glu-D1 (Chojecki et al., 1983 ) in wheat, and therefore, assuming gene synteny, analysis of the Gpi-1 phenotype of the dissociated protein selections allows homoeologous recombinants in the interval Gpi-1-Gli-1 to be distinguished from misdivision products and recombinants in the interval Glu-1-Gpi-1. Later the Gpi-1 phenotype of a sample of the undissociated protein individuals was also analysed to search for double recombinants.

\section{RESULTS}

Selection of $F_{2}$ individuals homozygous ph1b and carrying endosperm protein markers for both chromosomes $1 U$ and $1 B$ (or 1D)

The $F_{1}$ hybrids from crosses between substitution line $1 \mathrm{U}(1 \mathrm{~B}) \times p h 1 b$ mutant and $1 \mathrm{U}(1 \mathrm{D}) \times p h 1 b$ mutant were expected to be monosomic for both $1 \mathrm{U}$ and the wheat chromosome replaced in the substitution line. Pmcs in the hybrid involving the $1 \mathrm{~B}$ substitution showed most commonly $20^{\prime \prime}+2^{\prime}$ as expected, although an occasional trivalent or quadrivalent was seen and a few pmcs had as many as six univalents. Chromosome $1 \mathrm{U}$ remained unpaired in all pmcs analysed. The equivalent hybrid involving the $1 \mathrm{D}$ substitution was not meiotically analysed.

Three presumptive ph1bph1b selections were made among the $F_{2}$ plants carrying both storage protein markers of chromosomes $1 \mathrm{U}$ and $1 \mathrm{~B}$ derived from the cross $1 \mathrm{U}(1 \mathrm{~B}) \times$ ph $1 b$ mutant. The chiasma frequency in these plants was lower than the mean observed in eight sib plants presumed to be of constitution Ph1bph1b or Ph1bPh1b (i.e., $P h 1 b$-), manifested mainly by a higher average incidence of univalents and a marked increase in the proportion of rods to rings among the bivalents compared to the control (table 1). Chromosome $1 \mathrm{U}$ usually remained unpaired at metaphase I (fig. 1(a), but a heteromorphic rod bivalent was observed in two pmcs of plant 46-1 and in one pmc in plant 52-1 (fig. 1(b), table 1). The homozygous phlb status of these selections was confirmed by analysing the meiotic pairing in their hybrids with Ae. variabilis (Koebner and Shepherd, 1985). High levels of homoeologous pairing were observed at metaphase I in pmcs of five, four and five such intergeneric hybrid plants obtained from plants 45-2, 46-1 and 52-1, respectively.

The overall level of chromosome pairing in the $\mathrm{F}_{2}$ derived from $1 \mathrm{U}(1 \mathrm{D})$ was lower than in the equivalent $1 \mathrm{U}(1 \mathrm{~B})$ families. This difference is thought to be related to the two different stocks of the mutant parent crossed to the two substitution lines (cf. plant materials). Two phlbphlb selections (plants 114-1 and 115-1) were made among the $F_{2}$ plants derived from the $1 \mathrm{U}(1 \mathrm{D})$ cross on the basis of their chromosome pairing (table 2). Plant 114-1 was shown to have been phibphib when all five of its hybrids with Ae. variabilis exhibited homoeologous pairing at metaphase I. Only a single viable hybrid with Ae. variabilis was produced from plant $115-1$ and it showed homoeologous metaphase I pairing. The observation of a rod bivalent involving chromosome $1 \mathrm{U}$ in one pmc, and a ring bivalent in another pmc (table 2; figs. 1(c) (d) provided strong evidence that this plant was of genotype ph1bph $1 b$.

Table 1 Mean chromosome configurations at metaphase I in pmcs of selected $F_{2}$ plants from a cross between U(1B) $\times p h 1 b$ mutant

\begin{tabular}{|c|c|c|c|c|c|c|c|c|c|}
\hline $\begin{array}{l}\text { Plant } \\
\text { no. }\end{array}$ & $\begin{array}{l}\text { Somatic } \\
\text { chr. no. }\end{array}$ & univ. & rod & biv. & triv. & quad. & $\begin{array}{l}> \\
\text { quad. }\end{array}$ & $\begin{array}{l}\chi \text { per } \\
\text { pmc }\end{array}$ & $\begin{array}{l}\text { No. } \\
\text { pmes }\end{array}$ \\
\hline \multicolumn{10}{|c|}{ (i) $p h 1 b p h 1 b$ selections } \\
\hline $45-2$ & 43 & $\begin{array}{l}3 \cdot 4 \\
(2-5)^{*}\end{array}$ & $\begin{array}{l}4 \cdot 1 \\
(1-7)\end{array}$ & $\begin{array}{l}14 \cdot 0 \\
(11-17)\end{array}$ & $\begin{array}{l}0 \cdot 47 \\
(0-1)\end{array}$ & $\begin{array}{l}0 \cdot 47 \\
(0-1)\end{array}$ & - & $34 \cdot 5$ & 17 \\
\hline $46-1$ & 42 & $\begin{array}{l}3 \cdot 3 \\
(1-7)\end{array}$ & $\begin{array}{l}4 \cdot 5^{a} \\
(2-8)\end{array}$ & $\begin{array}{l}14 \cdot 4 \\
(12-18)\end{array}$ & $\begin{array}{l}0 \cdot 13 \\
(0-3)\end{array}$ & $\begin{array}{l}0 \cdot 11 \\
(0-1)\end{array}$ & $\begin{array}{l}0 \cdot 02 \\
(0-1)\end{array}$ & $34 \cdot 5$ & 53 \\
\hline $52-1$ & 43 & $\begin{array}{l}2 \cdot 5 \\
(1-7)\end{array}$ & $\begin{array}{l}5 \cdot 6^{\mathrm{b}} \\
(2-10)\end{array}$ & $\begin{array}{l}14 \cdot 2 \\
(10-18)\end{array}$ & - & $\begin{array}{l}0 \cdot 17 \\
(0-2)\end{array}$ & $\begin{array}{l}0.02 \\
(0-1)\end{array}$ & $34 \cdot 6$ & 41 \\
\hline \multicolumn{10}{|c|}{ (ii) $P h l b-$ (mean of eight plants) } \\
\hline & 42 & $\begin{array}{l}2 \cdot 3 \\
(1-6)\end{array}$ & $\begin{array}{l}2 \cdot 4 \\
(0-7)\end{array}$ & $\begin{array}{l}17 \cdot 2 \\
(13-20)\end{array}$ & $\begin{array}{l}0.07 \\
(0-1)\end{array}$ & $\begin{array}{l}0 \cdot 06 \\
(0-1)\end{array}$ & - & $37 \cdot 1$ & 231 \\
\hline
\end{tabular}

\footnotetext{
* Range.

a includes 2 pmcs with a bivalent involving $1 \mathrm{U}$.

${ }^{b}$ Includes 1 pmc with a bivalent involving $1 \mathrm{U}$. univ. = univalents, biv. = bivalents, triv. = trivalents, quad. $=$ quadrivalents,

$>$ quad. $=$ higher multivalents. $\chi=$ chiasmata.
} 
Table 2 Mean chromosome configurations at metaphase $\mathrm{I}$ in pmcs of selected $\mathrm{F}_{2}$ plants from a cross between $1 \mathrm{U}(1 \mathrm{D}) \times p h 1 b$ mutant

\begin{tabular}{|c|c|c|c|c|c|c|c|c|c|}
\hline $\begin{array}{l}\text { Plant } \\
\text { no. }\end{array}$ & $\begin{array}{l}\text { Somatic } \\
\text { chr. no. }\end{array}$ & univ. & rod & biv. & triv. & quad. & $\begin{array}{l}> \\
\text { quad. }\end{array}$ & $\begin{array}{l}\chi \text { per } \\
\text { pmc }\end{array}$ & $\begin{array}{l}\text { No. } \\
\text { pmcs }\end{array}$ \\
\hline \multicolumn{10}{|c|}{ (i) $p h 1 b p h 1 b$ selections: } \\
\hline $114-1$ & 42 & $\begin{array}{l}2 \cdot 8 \\
(1-8)^{*}\end{array}$ & $\begin{array}{l}4 \cdot 6 \\
(1-9)\end{array}$ & $\begin{array}{l}14 \cdot 5 \\
(9-18)\end{array}$ & $\begin{array}{l}0 \cdot 19 \\
(0-1)\end{array}$ & $\begin{array}{l}0 \cdot 12 \\
(0-1)\end{array}$ & - & $34 \cdot 3$ & 65 \\
\hline $115-1$ & 43 & $\begin{array}{l}2 \cdot 4 \\
(1-9)\end{array}$ & $\begin{array}{l}5 \cdot 4^{a} \\
(1-9)\end{array}$ & $\begin{array}{l}14 \cdot 2^{a} \\
(9-20)\end{array}$ & $\begin{array}{l}0.04 \\
(0-1)\end{array}$ & $\begin{array}{l}0 \cdot 26 \\
(0-1)\end{array}$ & $\begin{array}{l}0.04 \\
(0-1)\end{array}$ & $34 \cdot 9$ & 46 \\
\hline \multicolumn{10}{|c|}{ (ii) $P h 1 b$ (mean of four plants) } \\
\hline & 42 & $\begin{array}{l}2 \cdot 7 \\
(2-6)\end{array}$ & $\begin{array}{l}2 \cdot 9 \\
(0-9)\end{array}$ & $\begin{array}{l}16 \cdot 2 \\
(10-20)\end{array}$ & $\begin{array}{l}0 \cdot 13 \\
(0-1)\end{array}$ & $\begin{array}{l}0 \cdot 21 \\
(0-1)\end{array}$ & 一 & $36 \cdot 2$ & 108 \\
\hline
\end{tabular}

* range.

a includes 1 pmc with a bivalent involving $1 \mathrm{U}$. univ. = univalents, biv. = bivalents, triv. $=$ trivalents, quad. = quadrivalents,

$>$ quad $=$ higher multivalents. $\chi=$ chiasmata.

\section{Analysis of the $1 U(1 B)$ derived $T$ and $C$ populations}

Isolation of individuals having dissociated Gli-1 and Glu-1 markers

All three presumptive $p h 1 b$ homozygotes selected from the $F_{2}$ of the cross $1 \mathrm{U}(1 \mathrm{~B}) \times p h 1 b$ mutant were highly self-fertile. A total of 1322 seeds were analysed by SDS-PAGE to determine their Gli-1 and Glu-1 phenotypes. The Gli-1 phenotypes of the two parents were distinguished by the presence of clearly-separated bands on unreduced SDSPAGE gels (fig. 2A(a)) and these bands could be reliably scored in the progeny seed (Fig. 2A(b)). The Glu-1 phenotypes were scored in reduced SDS-PAGE gels and the glutelin subunits known to be controlled by chromosomes 1B (Payne and

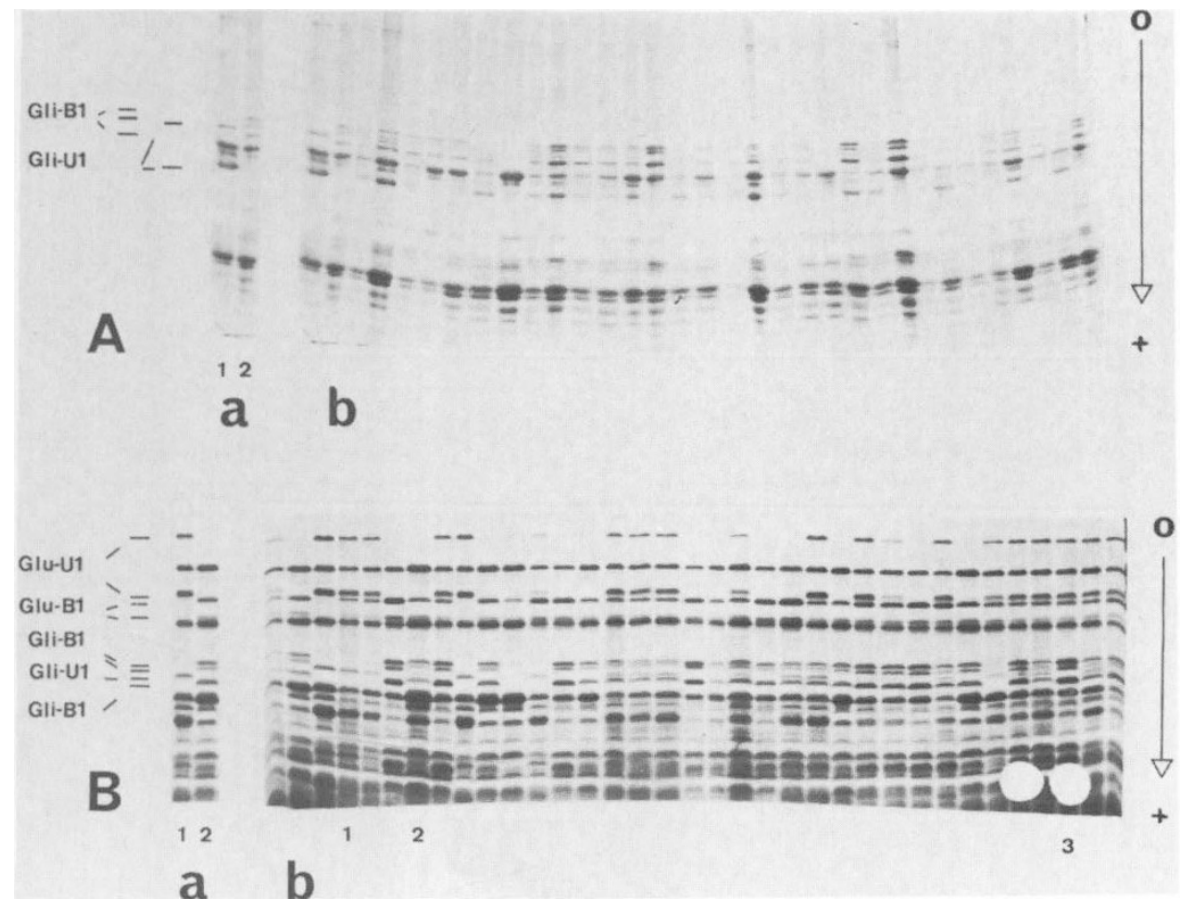

Figure 2 Endosperm protein phenotype of parents and segregating progeny derived from the cross substitution $1 \mathrm{U}(1 \mathrm{~B})$ ph $1 b$

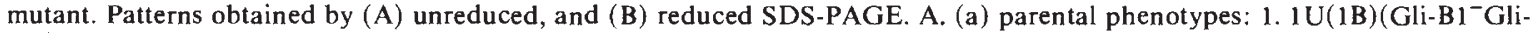
$\left.\mathrm{Ul}^{+}\right)$, 2. Euploid Chinese Spring $(\mathrm{CS})\left(\mathrm{Gli}-\mathrm{Bl}^{+} \mathrm{Gli}-\mathrm{Ul}^{-}\right)$; (b) progeny phenotypes. B. (a) parental phenotypes: $1.1 \mathrm{U}(1 \mathrm{~B})(\mathrm{Glu}-$ $\left.\mathrm{Bl}^{-}{ }^{-} \mathrm{Glu}-\mathrm{U} 1^{+}\right), 2$. Euploid $\mathrm{CS}\left(\mathrm{Glu}-\mathrm{B} 1^{+} \mathrm{Glu}-\mathrm{U} 1^{-}\right)$; (b) progeny phenotypes: 1. Glu-B1 ${ }^{+} \mathrm{Glu}-\mathrm{U} 1^{+} \mathrm{Gli}-\mathrm{B} 1^{-} \mathrm{Gli}-\mathrm{U} 1^{+}, 2 . \mathrm{Glu}-\mathrm{B} 1^{+} \mathrm{Glu}-$ $\mathrm{U}^{-}{ }^{-} \mathrm{Gli}-\mathrm{B} 1^{+} \mathrm{Gli}-\mathrm{U} 1^{+}, 3$. Glu-B1 ${ }^{+} \mathrm{Glu}-\mathrm{U} 1^{+} \mathrm{Gli}-\mathrm{Bl}{ }^{+} \mathrm{Gli}-\mathrm{U} 1^{-}$. 
Lawrence, 1983) and 1 U (Lawrence and Shepherd, 1981) could also be easily distinguished in both parents and progeny (fig. 2B(a), (b)). Although the Gli-1 phenotypes could often be scored on the same gels, the relevant bands sometimes overlapped other wheat bands, and therefore protein extracts were routinely analysed in both unreduced and reduced gels.

From the segregation patterns of the Gli-1 and Glu-1 proteins in these progeny (table 3 ), it was concluded that plant 52-1 was disomic for $1 \mathrm{~B}$ and monosomic for $1 \mathrm{U}$, while both 45-2 and 46-1 were monosomic for both these chromosomes. As the two non-homologous chromosomes $1 \mathrm{~B}$ and $1 \mathrm{U}$ are expected to only pair infrequently in $p h 1 b$ homozygotes, and not at all in the control Ph1bph1b parent, the segregation of the markers controlled by these chromosomes can be considered separately, giving rise to four phenotypic classes for both the $1 \mathrm{~B}$ and the $1 \mathrm{U}$ controlled proteins (table 3 ).

It was not possible to pool the data from all three $T$ populations because of the different behaviour of plant 52-1. Furthermore, although the segregation patterns of the progeny of plants 45-2 and 46-1 were homogeneous for the chromosome $1 \mathrm{U}$ classification $\left(\chi^{2}=0.30,3\right.$ df $0.95<p<$ $0.98)$, they were heterogeneous for the chromosome 1B classification $\left(\chi^{2}=11 \cdot 25,3\right.$ df $0.01<p<$ $0 \cdot 02)$. The pooled data obtained from the two $T$ populations 45-2 and 46-1 were clearly not homogeneous with those from the $\mathrm{C}$ population (progeny of plant 178-2) for either the chromosome $1 \mathrm{~B}\left(\chi^{2}=38 \cdot 2,3 \mathrm{df} p<0 \cdot 01\right)$ or for the chromosome $1 \mathrm{U}$ classifications $\left(\chi^{2}=16 \cdot 6,3 \mathrm{df} p<0 \cdot 01\right)$. For simplicity, the pooled 45-2 and 46-1 progeny will be referred to hereafter as the $\mathrm{T} 1$ population, and the progeny of plant 52-1 as the T2 population.

Progeny with dissociated Gli-1 and Glu-1 markers were detected in both the $\mathrm{T}$ and the $\mathrm{C}$ populations. In the control population such individuals are expected to arise only from chromosome misdivision and transmission of a telocentric arm, as any homoeologous pairing in the presence of $P h 1$ is very rare; by contrast, in the $T$ populations allosyndetic recombination also contributes to this class. Therefore it was surprising that the frequency of dissociated $1 \mathrm{~B}$ markers was more frequent in the $C$ population ( 13.6 per cent) than in the T1 population (11.1 per cent). This apparent anomaly may be a consequence of the absence of pairing of chromosome $1 \mathrm{~B}$ in the meiocytes of the Ph1bph1b parent, while some pairing does presumably occur in the ph1bph $1 b$ parents, thus allowing a higher rate of misdivision in the former plant. The frequency of the Glu$\mathrm{B} 1^{+} \mathrm{Gli}-\mathrm{B} 1^{-}$types was higher than Glu-B1- Gli$\mathrm{Bl}^{+}$, and this is probably due to differences in the transmission rate of the long and short arm telocentrics.

Fewer dissociated $1 \mathrm{U}$ marker individuals were obtained in the $\mathrm{C}$ population $(8.0$ per cent) than in the T1 $(11.0$ per cent $)$ or $T 2(11.1$ per cent $)$ populations, and also fewer than were recorded

Table 3 Endosperm storage protein phenotypes and their frequencies in the $\mathrm{T}$ and $\mathrm{C}$ populations derived from the cross $1 \mathrm{U}(1 \mathrm{~B}) \times$ phib mutant

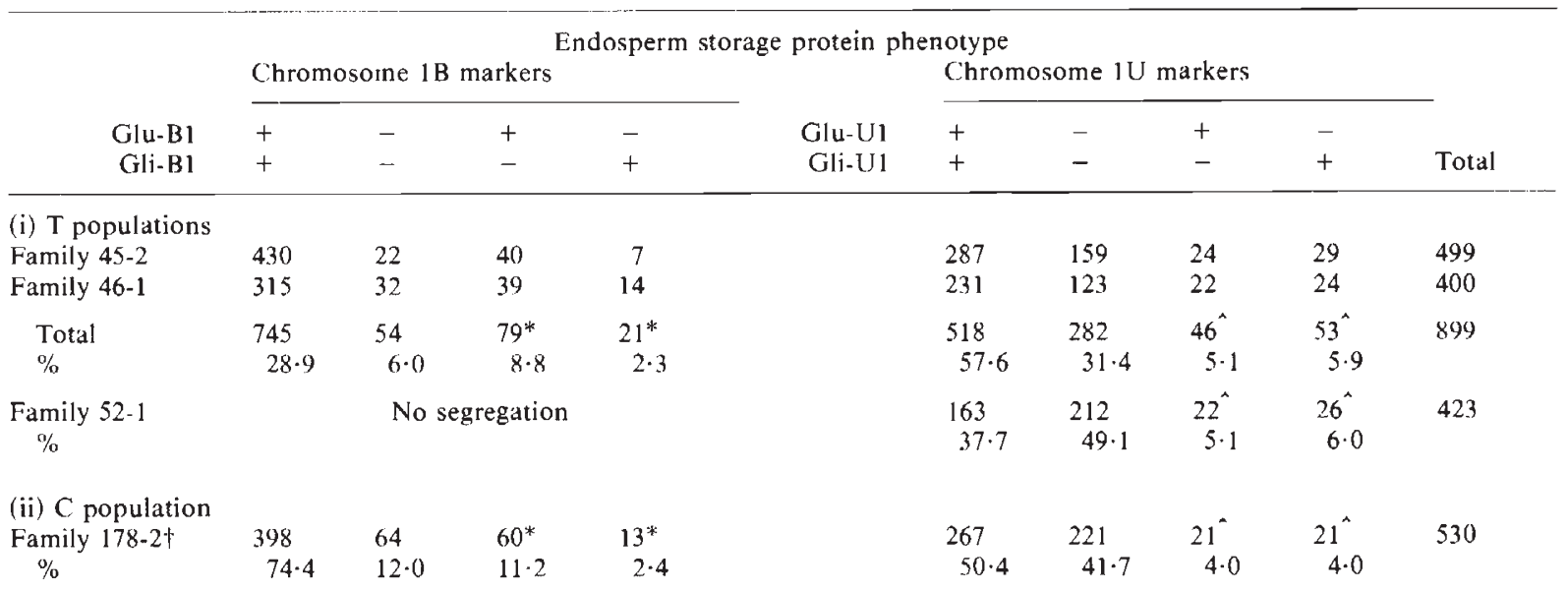

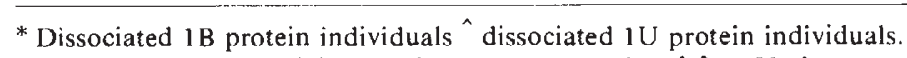

$\uparrow 5$ individuals analysed for $1 \mathrm{~B}$ phenotype not analysed for $1 \mathrm{U}$ phenotype, T: ph $1 b p h 1 b$-derived populations $C:$ Ph $1 b p h 1 b$-derived population 
with the $1 \mathrm{~B}$ markers. The lower recovery rate of individuals having dissociated $1 \mathrm{U}$ markers may be due to a lower rate of misdivision of chromosome $1 \mathrm{U}$ compared to $1 \mathrm{~B}$, or a lower transmission of $1 \mathrm{U}$ misdivision products through the gametes. Unlike with the $1 \mathrm{~B}$ markers, the $1 \mathrm{U}$ markers showed no marked difference in the frequency of the two classes of dissociated protein type. However the frequency of progeny carrying at least one of the $1 \mathrm{U}$ markers was much greater in the $\mathrm{T} 1$ population (68.6 per cent) than in the T2 population $(50.9$ per cent), probably reflecting the expected difference in transmission of an alien chromosome when present as a univalent in a 42 -chromosome double monosomic rather than as the extra chromosome in a 43-chromosome monosomic addition line.

\section{Gpi phenotype of dissociated Gli-1, Glu-1 selections}

From the $\mathrm{C}$ population, 73 progeny with dissociated chromosome $1 \mathrm{~B}$ markers and 42 with dissociated $1 \mathrm{U}$ markers were detected. Among the $\mathrm{T}$ populations, there were 100 such $1 \mathrm{~B}$ selections and $1471 \mathrm{U}$ selections (table 3 ). The Gpi phenotypes of these individuals were analysed to distinguish allosyndetic recombinants in the interval Gpi-1Gli-1 from misdivision products and recombinants in the interval Glu-1-Gpi-1. The CAE phenotype of normal wheat gives four strong bands and a fifth, faster, weak band (fig. 3A). In the absence of chromosome $1 \mathrm{~B}$, or its short arm, the slowest two bands are lost (see Hart, 1979). Gpi-U1 controls the most anodal band on the IEF gels (Chojecki and Gale, 1982) and was used to score for the presence of this locus (fig. 3B). The gel shown in fig. 3A also reflects segregation for Gpi$U 1$, and thus more than four strong bands are visible in some samples; however this system did not prove sufficiently reliable for the analysis of segregation for this locus. The frequencies of the Gpi-1 phenotypes among the selected progeny are given in table 4.

Due to a technical fault, a number of the $1 \mathrm{~B}$ selections from the $C$ population could not be scored for the presence of $G p i-B 1$, but all of the 48 analysed retained the linkage $G p i-B 1-G l i-B 1$ as did all 42 of the $1 \mathrm{U}$ selections for Gpi-U1-Gli-U1 (table 4), as expected if all of the progeny of plant 178-2 with dissociated endosperm protein markers resulted from chromosome misdivision, and not allosyndetic recombination. In contrast, many of the selections obtained from the $T$ populations showed a disruption in the Gpi-1-Gli-1 association, indicating the occurrence of allosyndetic recombination, presumably induced by the loss of normal

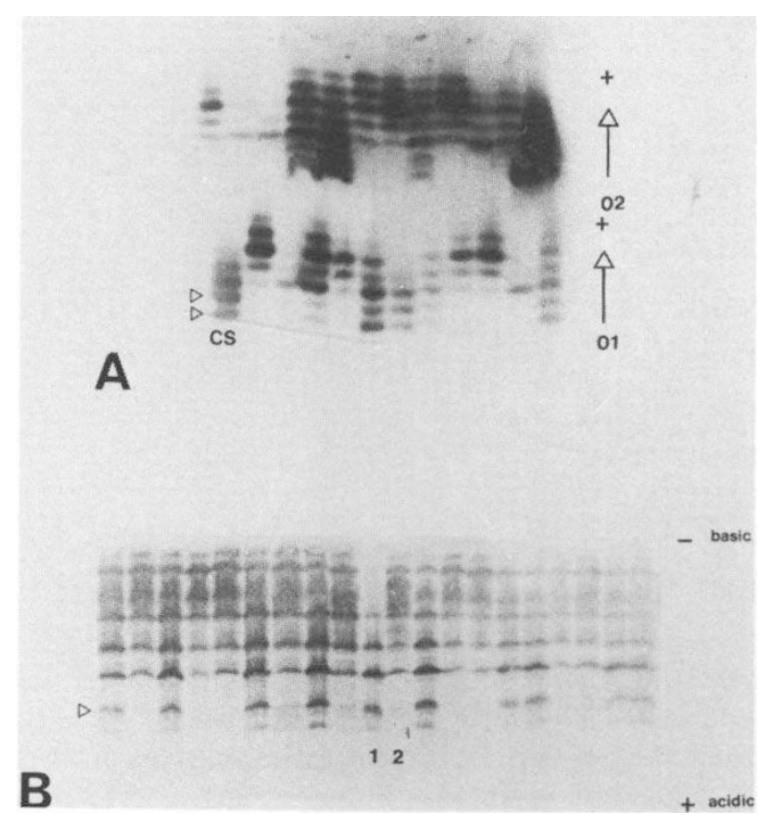

Figure 3 Glucose phosphate isomerase phenotypes of parents and segregating progeny derived from the cross substitution $1 \mathrm{U}(1 \mathrm{~B}) \times$ phlb mutant. A. Cellulose acetate zymogram. CS-Euploid Chinese Spring. Other samples represent progeny segregating for $G p i-B I$ and $G p i-U 1$. Bands controlled by $G$ pi-BI shown by $D$. 01: loading start for bottom row of samples; 02: loading start for top row of samples. B. Isoelectric focussing zymogram (nominal $\mathrm{pH}$ gradient 3 10). Parental phenotypes: 1. Substitution 1U(1B), 2. Euploid Chinese Spring. Other samples represent progeny segregating for Gpi-U1. Band used for scoring Gpi-U1 phenotype shown by $D$

$P h 1$ activity. Of the 15 recombinants in the segment Gpi-B1-Gli-B1, 13 were Glu-B1 ${ }^{+} \mathrm{Gpi}^{-\mathrm{B}}{ }^{-} \mathrm{Gli}^{-\mathrm{B}} 1^{+}$, while 2 were of the reciprocal type (table 4 ). Since the former type retained much more $1 \mathrm{~B}$ chromatin than the latter, it is likely that they will be more easily transmitted through the pollen than the other type. The proportion of Gpi-U1-Gli-U1 recombinants ( 42 out of $147=29$ per cent) was, surprisingly, much more frequent than that observed for the equivalent segment of chromosome 1B (15 out of $100=15$ per cent), but in the former case there was less of a difference in the frequency of the reciprocal recombinant types ( 25 versus 17 , table 4).

Despite the identification of these definite allosyndetic recombinants, the great majority of the $\mathrm{T}$ population selections had parental combinations of these short arm markers- 85 per cent for chromosome $1 \mathrm{~B}$ and 71.4 per cent for chromosome $1 \mathrm{U}$ (table 4). This group of progeny will include all those possessing misdivision products, and 
Table 4 Gpi phenotypes of individuals selected as having dissociated endosperm protein markers in the $T$ and $C$ populations

\begin{tabular}{|c|c|c|c|c|c|c|c|c|c|c|}
\hline \multirow[b]{4}{*}{ (i) $\mathrm{T}$ populations } & \multicolumn{9}{|c|}{ Endosperm protein and Gpi phenotype } & \\
\hline & \multicolumn{2}{|c|}{$\left[\mathrm{Glu}-\mathrm{B} 1^{+} \mathrm{Gli}-\mathrm{B} 1^{-}\right]$} & \multicolumn{3}{|c|}{$\left[\right.$ Glu-B1 ${ }^{-}$Gli-B1 $\left.{ }^{+}\right]$} & \multicolumn{2}{|c|}{$\left[\right.$ Glu-U1 ${ }^{+}$Gli-U1 $\left.^{-}\right]$} & \multicolumn{3}{|c|}{ [Glu-U1 Gli-U1 ${ }^{+}$] } \\
\hline & \multicolumn{2}{|c|}{$\mathrm{Gpi}^{-B 1^{-} \mathrm{Gpi}-\mathrm{B} 1^{+}}$} & \multicolumn{3}{|c|}{$\mathrm{Gpi-B1}{ }^{+} \mathrm{Gpi}-\mathrm{B} 1^{-}$} & \multicolumn{2}{|c|}{$\mathrm{Gpi}^{\mathrm{U}} 1^{-}{ }^{-} \mathrm{Gpi}-\mathrm{U} 1^{+}$} & \multicolumn{3}{|c|}{ Gpi-U1 ${ }^{+}$Gpi-U1- } \\
\hline & & & & & Total & & & & & Total \\
\hline Family $45-2$ & 36 & 4 & 6 & 1 & & 13 & 11 & 21 & 8 & \\
\hline Family $46-1$ & 30 & 9 & 13 & 1 & & 12 & 10 & 20 & 4 & \\
\hline Family $52-1$ & & & & & & 18 & 4 & 21 & 5 & \\
\hline Total & 66 & $13^{\wedge}$ & 19 & $2 \hat{\imath}$ & 100 & 43 & $25^{\wedge}$ & 62 & $17^{\wedge}$ & 147 \\
\hline (ii) $\mathrm{C}$ population & & & & & & & & & & \\
\hline Family $178-2$ & 37 & 0 & 11 & 0 & $48^{*}$ & 21 & 0 & 21 & 0 & 42 \\
\hline
\end{tabular}

Recombinants in the interval Gpi-1-Gli-1.

* 25 individuals in these endosperm protein classes not scored for Gpi-B1 T: ph1bph1b-derived populations C: Ph1bphlb-derived population

others having allosyndetic recombination in the interval Glu-1-Gpi-1. These two types are indistinguishable in the absence of other markers in this chromosome segment without extensive cytological analyses.

The above annalysis of recombination was based on the assumption of a maximum of one homoeologous single cross-over per chromosome. In order to test this assumption, a sample of 211 from the $\mathrm{T} 1$ and 116 from the $\mathrm{T} 2$ populations having undissociated storage protein markers (i.e., Glu- $1^{+}$Gli- $1^{+}$and Glu- $1^{-}$Gli-1 ${ }^{-}$), was analysed for Gpi phenotype. Both Gpi-U1 and Gpi-B1 phenotypes were scored on IEF gels for this purpose, and the results are given in table 5. If no double cross-overs had occurred, all progeny which possessed both Glu-B1 and Gli-B1 would also possess $G p i-B 1$, while those individuals lacking these storage proteins would also lack Gpi-B1, and similarly for the loci controlled by chromosome $1 \mathrm{U}$. Although the majority of seeds sampled showed a Gpi phenotype consistent with there having been no double cross-over between the three loci under consideration, a few double crossovers were detected along chromosome $1 \mathrm{U}(5 \cdot 7$ per cent in the $T 1$, and $4 \cdot 3$ per cent in the $T 2$ populations) and along $1 \mathrm{~B}$ ( 1.9 per cent in the T1 population). The higher frequency of recovery of homoeologous double cross-overs involving chromosome $1 \mathrm{U}$ rather than $1 \mathrm{~B}$ is consistent with the greater frequency of single cross-overs in the interval Gpi-U1-Gli-U1 compared to those in the interval Gpi-B1-Gli-B1, as noted earlier.

\section{Analysis of the $1 U(1 D)$ derived populations}

A sample of 268 progeny from each of the two plants identified as phibphlb from the cross $1 \mathrm{U}(1 \mathrm{D}) \times p h 1 b$ mutant was analysed electrophoretically, to compare with the results obtained with the $1 \mathrm{U}(1 \mathrm{~B})$ cross. The observed frequencies of the Gli-1 and Glu-1 storage protein phenotypes determined by SDS-PAGE are listed in table 6, and typical patterns are illustrated in fig. 4A, B. Progeny of plant 115-1 (with somatic chromosome number of 43, table 2) did not segregate for either Gli-D1 or Glu-D1 and this plant was therefore thought to be disomic for chromosome 1D. However progeny from both of the selected plants segregated for Gli-U1 and Glu-U1.

Table 5 Frequency and phenotype of double homoeologous cross-over individuals involving (a) chromosome $1 \mathrm{~B}$, and (b) chromosome $1 \mathrm{U}$, sampled from the $\mathrm{T}$ populations

\begin{tabular}{|c|c|c|c|}
\hline & \multicolumn{2}{|c|}{ Endosperm phenotype } & $\%$ occurrence \\
\hline (a) Chromosome 1B & $\left(\mathrm{Glu}-\mathrm{B} 1^{+} \mathrm{Gpi}^{-B} 1^{-} \mathrm{Gli}-\mathrm{B} 1^{+}\right)$ & $\left(\mathrm{Glu}-\mathrm{B} 1^{-} \mathrm{Gpi}-\mathrm{B} 1^{+} \mathrm{Gli}-\mathrm{B} 1^{-}\right)$ & \\
\hline T1 population & 1 & 3 & 1.9 \\
\hline (b) Chromosome $1 \mathrm{U}$ & $\left(\right.$ Glu-U1 ${ }^{+}$Gpi-U1-Gli-U1 ${ }^{+}$) & (Glu-U1-Gpi-U1 ${ }^{+}$Gli-U1 ${ }^{-}$) & \\
\hline T1 population & 5 & 7 & $5 \cdot 7$ \\
\hline T2 population & 2 & 3 & $4 \cdot 3$ \\
\hline
\end{tabular}

T1: progeny of 42 chromosome ph1bphlb plants $45-2$ and $46-1$.

T2: progeny of 43 chromosome phipbh1b plant 52-1. 
Table 6 Storage protein phenotypes and their frequencies in progeny of two ph $1 b p h 1 b$ plants selected in the $\mathrm{F}_{2}$ generation from the cross $1 \mathrm{U}(1 \mathrm{D}) \times$ ph $1 b$ mutant

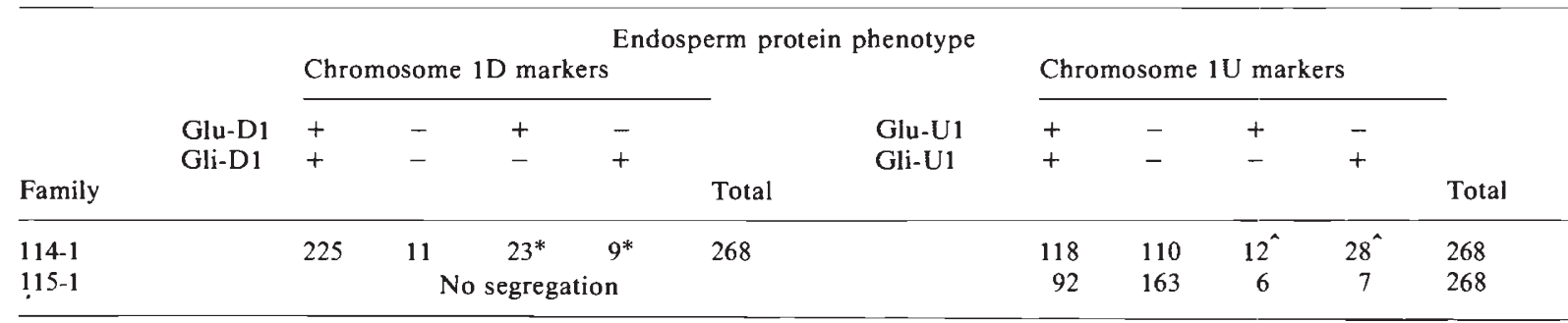

* Dissociated 1D protein individuals. ^Dissociated $1 \mathrm{U}$ protein individuals. $+=$ protein present, $-=$ protein absent.

The equivalent $\mathrm{F}_{2}$ control population was not analysed as before, as the previous experiment had already shown that no allosyndetic recombinations occurs in the presence of one dose of $P h 1$.

The progenies of plants 114-1 and 115-1, respectively, gave different segregation patterns for the $1 \mathrm{U}$ controlled proteins, similar to the differences observed earlier with the T1 and T2 populations arising from the $1 \mathrm{U}(1 \mathrm{~B})$ cross. Thus the plant which was monosomic for chromosome $1 \mathrm{D}$ gave a higher proportion of progeny containing all or part of chromosome $1 \mathrm{U}$ (59 per cent) than the disomic $1 \mathrm{D}$ parent where this proportion was only 39 per cent (table 6). Among the individuals having dissociated $1 \mathrm{U}$ storage protein phenotypes, the Glu-U1- ${ }^{-}$Gli-U1 ${ }^{+}$phenotype was more frequent than its reciprocal phenotype (13.1 per cent versus 6.7 per cent). A preponderance of this phenotype, although less marked, was also noted in the progeny from the $1 \mathrm{U}(1 \mathrm{~B})$ cross.

The 1D chromosomes showing a dissociated storage protein phenotype were not analysed further. However, the 53 individuals with dissociated $1 \mathrm{U}$ markers (18 Glu-U1 ${ }^{+} \mathrm{Gli}-\mathrm{U} 1^{-}$and $35 \mathrm{Glu}$ $\mathrm{U}^{-}{ }^{-} \mathrm{Gli}-\mathrm{U} 1^{+}$) were scored for their Gpi-U1 phenotypes (table 7). A total of 23 further recombinants involving the segment of chromosomes $1 \mathrm{U}$ between Gpi-U1 and Gli-U1 were thus identified.

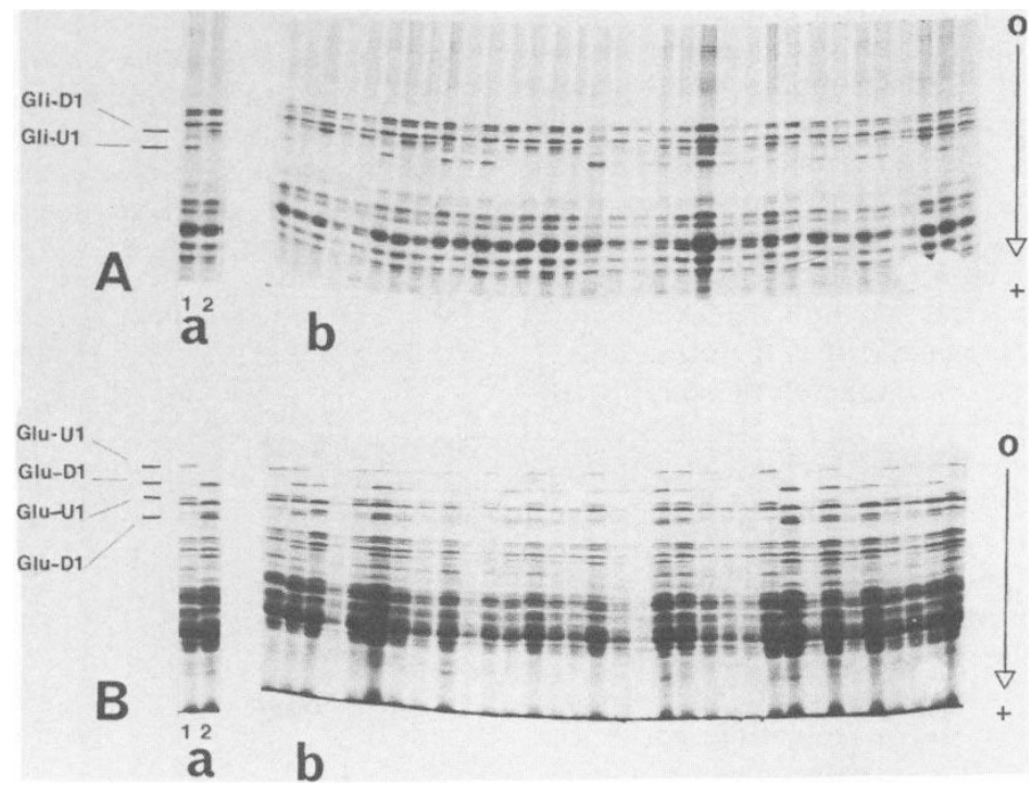

Figure 4 Endosperm protein phenotype of parents and segregating progeny derived from the cross substitution $1 \mathrm{U}(1 \mathrm{D}) \times$ ph $1 b$ mutant. Patterns obtained by (A) unreduced, and (B) reduced SDS-PAGE. A. (a) parental phenotypes: 1 . 1U(1D)(Gli-D1 ${ }^{-}$Gli$\left.\mathrm{U1}^{+}\right)$, 2. Euploid Chinese Spring (CS)(Gli-D1 $\left.{ }^{+} \mathrm{Gli}-\mathrm{U} 1^{-}\right)$; (b) progeny phenotypes. B. (a) parental phenotypes: 1. 1U(1D)(Glu$\left.\mathrm{Dl}^{-} \mathrm{Glu}-\mathrm{U} 1^{+}\right), 2$. Eucploid $\mathrm{CS}\left(\mathrm{Glu}-\mathrm{D} 1^{+} \mathrm{Glu}-\mathrm{U} 1^{-}\right)$; (b) progeny phenotypes. 
Table 7 Gpi phenotypes of progeny selected as having dissociated endosperm protein markers in two ph 1 bph 1 b-derived families

\begin{tabular}{|c|c|c|c|c|c|}
\hline \multicolumn{6}{|c|}{ Non-parental phenotype } \\
\hline & \multicolumn{2}{|c|}{$\left(\text { Glu-U1 }{ }^{+} \mathrm{Gli}^{-\mathrm{U} 1^{-}}\right)^{-}$} & \multicolumn{2}{|c|}{ (Glu-U1 ${ }^{-}$Gli-U1 $\left.{ }^{\dagger}\right)$} & \\
\hline & Gpi-U1- & $\mathrm{Gpi}^{-\mathrm{U1}^{+}}$ & $\mathrm{Gpi}_{\mathrm{U}} \mathbf{1}^{+}$ & $\mathrm{Gpi}_{-} \mathrm{U1}^{-}$ & \\
\hline $114-1$ & 6 & 6 & 14 & 14 & \\
\hline $115-1$ & 4 & 2 & 6 & 1 & \\
\hline Total & 10 & $8^{*}$ & 20 & $15^{*}$ & 53 \\
\hline
\end{tabular}

* Recombinants in the interval Gpi-U1-Gli-U1.

\section{DISCUSSION}

It would be of interest to derive an estimate of the recombination frequency induced by $p h 1 b p h 1 b$ between the various marker loci on chromosome $1 \mathrm{U}$. However, to obtain this, the transmission rate of a complete, unaltered chromosome $1 \mathrm{U}$ through both the male and female gamete in a plant monosomic for this chromosome needs to be known, for the presence of such a complete chromosome $1 \mathrm{U}$ in a progeny seed will mask the presence of a recombinant chromosome in the same individual. The analysis of the segregation of a wheat and an alien chromosome, present as two monosomes, is complex when the plant is allowed to self-fertilise. However, studies of such systems indicate that if the alien chromosome can successfully substitute for the wheat monosome (i.e., the wheat and alien chromosomes are homoeologous), then the transmission of the alien chromosome through the female gamete is approximately $1 / 4$, while the male transmission rate is $4 / 7$ (Knott, 1964). The analysis of the present material is complicated by the occurrence of homoeologous pairing which reduces the frequency with which the two monosomes remain as univalents at metaphase I. It is therefore only possible to derive an approximate estimate of the frequency of allosyndetic recombination achieved between chromosome $1 \mathrm{U}$ and chromosomes of the wheat genome, and this estimate must be treated with some caution.

The observed relative frequencies of the various chromosome $1 \mathrm{U}$ controlled phenotypes recovered from the $\mathrm{T} 1$ and the $\mathrm{T} 2$ populations are shown separately in table 8 , as the distributions of these phenotypes have been shown to be different. The relative frequency of the chromosomes classified as parental (" +++ " and " - - ") was adjusted in table 8 by subtracting that of the double crossovers which have the same storage protein phenotype. Taking $m_{0}$ and $f_{0}$ to be the relative frequencies with which male and female gametes lacking chromosome $1 \mathrm{U}$ function, equating the expected relative frequency of the phenotypic class " _ _ _ $\left(m_{0} f_{0}\right)$ with its observed frequency and taking $f_{0}$ to be 0.75 (Sears, 1954; Tsunewaki, 1963), this gives an estimate for $m_{0}$ of 0.376 and 0.633 for each type of population, respectively. The male transmission rate of the alien monosome from the double monosomic 42 chromosome plants is thus estimated to be 0.624 (i.e., $1-m_{0}$ ), and this accords well with the theoretical value of $4 / 7(0.571)$.

Metaphase I pairing data is known to be a poor indicator of genetic recombination, since desynaptic univalents which were paired at prophase I are indistinguishable from asynaptic univalents which had never been paired (Fu and Sears, 1973). Homologous segments of alien chromosomes have been observed often to exhibit pairing failure when in a wheat background (Singh and Shepherd, 1984), and it is therefore likely that homoeologous bivalents are prone to such desynapsis, which is taken to explain the discrepancy between the low frequency of observed metaphase I bivalents involving chromosome $1 \mathrm{U}$ (tables 1,2 ) and the

Table 8 Relative frequencies of chromosome $1 \mathrm{U}$ controlled phenotypes in the $\mathrm{T} 1$ and $\mathrm{T} 2$ populations (1U(1B) cross)

\begin{tabular}{|c|c|c|c|c|}
\hline \multicolumn{3}{|c|}{ Progeny phenotype } & \multicolumn{2}{|c|}{ Relative frequency } \\
\hline Glu-U1 & Gpi-U1 & Gli-U1 & $\mathrm{T} 1$ & $\mathrm{~T} 2$ \\
\hline- & - & - & 0.282 & 0.475 \\
\hline+ & + & + & 0.552 & 0.368 \\
\hline+ & - & - & 0.028 & 0.043 \\
\hline- & + & + & 0.046 & $0 \cdot 050$ \\
\hline+ & + & - & 0.023 & 0.009 \\
\hline- & - & + & 0.013 & 0.012 \\
\hline+ & - & + & 0.024 & $0 \cdot 017$ \\
\hline- & + & - & 0.032 & 0.026 \\
\hline
\end{tabular}

$+=$ presence of protein, $-=$ absence of protein.

T1: pooled progeny of 42 chromosome phlbphlb plants $45-2$ and 46-1.

T2: progeny of 43 chromosome phlbphlb plant 52-1. 
higher than expected numbers of recombinants. While it is recognised that desynapsis will result in differences in transmission of recombinant chromosomes through the male and female gametes, for simplicity it has been assumed in this analysis that the transmission of the two resulting recombinant chromosome types (phenotypes Gpi$\mathrm{U}^{+}{ }^{+} \mathrm{Gli}-\mathrm{U} 1^{-}$and $\mathrm{Gpi}-\mathrm{U} 1^{-} \mathrm{Gli}-\mathrm{U} 1^{+}$) is independent of whether the gamete containing the recombinant chromosome is male or female. A recombinant gamete will be detected only if the other gamete is null for chromosome $1 \mathrm{U}$, so that the expected relative frequency of such recombinants is given by $\left(m_{0}+f_{0}\right) r$, where $r$ is the probability of such a recombinant being formed and transmitted. Since chromosome 1U substitutes well for 1B (Shepherd, 1973; Chapman et al., 1975), it is reasonable to assume that there is little selection against recombinant gametes, and thus $r$ should represent a good estimate of the actual rate of allosyndetic recombination. The expression $\left(m_{0}+f_{0}\right) r$ has been used to estimate the values of $r$ for each of the two recombinant types in both the T1 and the T2 populations (table 9) by equating it to the observed relative frequencies of cross-overs in the interval Gpi-U1. Gli-U1. The frequency of occurrence of recombined progeny from the 42 chromosome (double monosomic) is nearly double that for the 43 chromosome (monosomic addition) plants. This result stresses the value of providing an alien chromosome with an unpaired homoeologue, and suggests that many of the recombinants in the $\mathrm{T} 1$ population involve exchange between chromosomes $1 \mathrm{U}$ and $1 \mathrm{~B}$.

It is of interest that, after correction of the chromosome $1 \mathrm{U}$ totals by subtracting the number of recombinants recovered in the progeny of plant $52-1$ which did not segregate for $1 \mathrm{~B}$, the relative frequency of recombinants in the interval Gpi-1Gli-1 was greater for chromosome $1 \mathrm{U}$ than for $1 \mathrm{~B}$ (table 4). Moreover, the relative frequency of

Table 9 Estimated relative frequencies of allosyndetic recombination in the interval Gpi-U1-Gli-U1 on chromosome $1 \mathrm{U}$ in the $\mathrm{T} 1$ and $\mathrm{T} 2$ populations (1U(1B) cross)

\begin{tabular}{lll}
\hline & $\mathrm{T} 1$ & $\mathrm{~T} 2$ \\
\hline$r_{2}$ & 0.048 & 0.025 \\
$r_{2}$ & 0.032 & 0.021 \\
Total & 0.080 & 0.046 \\
\hline
\end{tabular}

T1: pooled progeny of 42 chromosome $p h 1 b p h 1 b$ plants $45-2$ and $46-1$

T2: progeny of 43 chromsome ph $1 b p h 1 b$ plant 52-1.

$r_{1}=$ refers to phenotype $\mathrm{Gpi}-\mathrm{UI}^{+} \mathrm{Gli}-\mathrm{U1}^{-}$

$r_{2}=$ refers to phenotype Gpi-U1-Gli-U1 $1^{+}$ double cross-overs was substantially higher for chromosome $1 \mathrm{U}$ as compared to chromosome $1 \mathrm{~B}$ (table 5). These observations are consistent with the hypothesis that chromosome $1 \mathrm{U}$ is more closely related to its wheat homoeologues than is chromosome 1B. Cytological evidence for the close relationship between the chromosomes of the $\mathrm{U}$ and D genomes has been provided by Kihara (1949), who found up to five bivalents per pmc in the hybrid Ae. umbellulata $\times$ Ae. squarrosa, the species now accepted to be the progenitor of the $\mathrm{D}$ genome in hexaploid wheat (Morris and Sears, 1967). The identical electrophoretic patterns of the gene products of the homoeoloci Tri-D1 and TriU1 (N. K. Singh, personal communication) provide circumstantial biochemical support to the hypothesis of a close relationship between chromosomes $1 \mathrm{U}$ and $1 \mathrm{D}$. The finding that there are differences in pairing affinity between rye chromosome $1 \mathrm{R}$ and wheat chromosomes $1 \mathrm{~A}$ and $1 \mathrm{~B}$ (Naranjo, 1982) suggests that these two wheat chromosomes are not "equidistant" in an evolutionary sense from chromosome $1 \mathrm{R}$, and a similar difference may apply within the group of chromosomes 1A, 1B, 1D and 1U. Cytological studies with chromosome $1 \mathrm{U}$, similar to those of Naranjo (1982), are required to test this hypothesis.

In two independent chromosome 1D mapping experiments (Chojecki et al., 1983; Koebner, unpubl.), allelic variation between two wheat cultivars in Gpi-D1 and Gli-D1 on chromosome 1DS gave similar recombination values $(34.5$ per cent and 25.6 per cent, respectively) or three to four times greater than the rate estimated for homoeologous recombination along chromosome $1 \mathrm{U}(8.0$ per cent table 9$)$. This reduction in the rate of recombination between two well-spaced markers underlines the difficulty of separating loci which are closely linked on an alien chromosome, without recourse to large progeny populations. Screening of large numbers of progeny requires highly efficient, rapid and reliable methods such as those described in this work, where approximately 2400 individual seeds were analysed. Many of the markers, biochemical, molecular and especially cytological, so far described in wheat, require techniques for their identification which are too time-consuming to be of general use in alien introgression.

A major feature of the populations produced in this study is that the two storage protein markers used initially to isolate single cross-over events are distantly separated genetically, so that any new marker obtained, which is interstitial to these two loci, can be applied to the same population, which 
is still in the form of seed (less a small portion of endosperm). The embryos representing the nondissociated storage protein markers are also still intact, and residual entire seed from each of the ph 1 bph $1 b$ selections is still available for further analysis. The overall number of wheat-Aegilops recombinants involving segments of the $1 \mathrm{U}$ chromosome other than in the interval Gpi-U1-Gli$U 1$ cannot be estimated without further markers for chromosome $1 \mathrm{U}$. A gene controlling a grain lectin characteristic for Ae. umbellulata has been located on this chromosome, but the gene product cannot yet be assayed on a single grain basis (Stinissen et al., 1983). A series of molecular markers has been established for chromosome 1RS (c.f. Koebner et al., 1986), and it is likely that the probes developed for regions on $1 \mathrm{RS}$ will be useful in characterising the Gpi-U1-Gli-U1 recombinants from this study, as the rye loci Gpi-R1 and Sec-1 are both located in the region of 1 RS most characterised by these molecular markers.

The potential agronomic value of the recombinant lines produced in this study is limited. The introgression of the gene(s) controlling the HMW glutelin subunits coded for by Glu-U1 was thought worthwhile as a means of possibly improving the breadmaking quality of flour (Law and Payne, 1983), but the whole chromosome substitution lines involving $1 \mathrm{U}$ are known to suffer a yield disadvantage (Shepherd, 1973; Law and Payne, 1983). However glutenin subunits controlled by Glu-D1 with electrophoretically very similar mobility on SDS-PAGE to the Glu-U1 products have since been detected in five Japanese cultivars, although these proteins migrate to different gel positions under two dimensional electrophoretic separation (Payne et al., 1983). No genes conferring disease resistance are known to be located on chromosome $1 \mathrm{U}$. The value of the recombinant lines is likely to lie more in the opportunity they afford to map the group 1 wheat chromosomes. Genetic mapping requires allelic variation, and this variation is not common among biochemical characters in cultivated wheat. Deletion mapping presents an alternative procedure, and this has already been utilised to a limited extent in wheat (e.g., MacKey, 1954; Ainsworth et al., 1984). The wheat-alien recombination lines produced in this work make available a large number of genotypes which represent potentially many different breakpoints along the wheat chromosomes of homoeologous group 1; they are genetically equivalent to deletion lines providing the introgressed chromatin differs in its markers from those of wheat. They will therefore allow the establishment of gene order along these wheat chromosomes as various new markers located by aneuploid analysis to these chromosomes become available.

Acknowledgement The senior author is grateful to the University of Adelaide for the provision of a Scholarship for Postgraduate Research.

\section{REFERENCES}

AINSWORTH, C. C., JOHNSON, H. M., JACKSON, E. A., MILLER, T.E. AND GALE, M. D. 1984. The chromosomal locations of leaf peroxidase genes in hexaploid wheat, rye and barley. Theoretical and Applied Genetics, 69, 205-210.

CEOLONI, C. 1984. Incorporation of a mildew resistance gene derived from Triticum longissimum into common wheat through crossing-over between homoeologous chromosomes. In Proceedings of the 28 th annual meeting, Italian Society for Agricultural Genetics, Bracciano, 94-95.

CHAPMAN, V., RILEY, R. AND MILlER, T. E. 1975. Alien chromosome addition and substitution lines. Annual Report of the Plant Breeding Institute Cambridge, 1974, 125-126.

CHOJECKI, A. J. S. AND GALE, M. D. 1982. Genetic control of glucose phosphate isomerase in wheat and related species. Heredity, 49, 337-347.

CHOJECKI, A. J. S., GALE, M. D., HOLT, L. M. AND PAYNE, P. I. 1983. The intrachromosomal mapping of a glucose phosphate isomerase structural gene, using allelic variation among stocks of Chinese Spring wheat. Genetical Research (Cambridge), 41, 221-226.

DVó̌Á K, J. 1977. Transfer of leaf rust resistance from Aegilops speltoides to Triticum aestivum. Canadian Journal of Genetics and Cytology, 19, 133-141.

Frauenstein, K. AND HAMMER, K. 1985. Prüfung von Aegilops-Arten auf Resistenz gegen Echten Mehltau, Erisyphe graminis DC, Braunrost, Puccinia recondita Rob. ex Desm., und Spelzenbräune, Septoria nodorum Berk. Kulturpflanze, 33, 155-163.

FU, $\Upsilon$. K. AND SEARS, E. R. 1973. The relationship between chiasmata and crossing over in Triticum aestivum. Genetics, $75,231-246$.

HART, G. E. 1979. Evidence for a triplicate set of glucose phosphate isomerase structural genes in hexaploid wheat. Biochemical Genetics, 17, 585-597.

HART, G. E., ISLAM, A. K. M. R. AND SHEPHERD, K. W. 1980 Use of isozymes as chromosome markers in the isolation of wheat-barley chromosome addition lines. Genetical Research (Cambridge), 36, 311-325.

KiHARA, H. 1949. Genomanalyse bei Triticum und Aegilops. IX. Systematischen Aufbau der Gattung Aegilops auf genomanalytischen Grundlage. Cytologia, 14, 135-144.

KNOTT, D. R. 1964. The effect on wheat of an Agropyron chromosome carrying rust resistance. Canadian Journal of Genetics and Cytology, 6, 500-507.

KOEBNER, R. M. D. AND SHEPHERD, K. W. 1985. Induction of recombination between rye chromosome $1 \mathrm{RL}$ and wheat chromosomes. Theoretical and Applied Genetics, 71, 208215.

KOEBNER, R. M. D., SHEPHERD, K. W. AND APPELS, R. 1986 Controlled introgression into wheat of genes from rye chromosome 1 RS by induction of allosyndesis. 2. Characterisation of recombinants. Theoretical and Applied Genetics, 73, 209-217. 
LAW, C. N. 1984. Transfer of genes for grain protein type from Aegilops umbellulata into wheat. Annual Report of the Plant Breeding Institute Cambridge 1983, 58-59.

LAW, C. N. AND PAYNE, P. I. 1983. Genetical aspects of breeding for improved grain protein content and type in wheat. Journal of Cereal Science, 1, 79-93.

LAWRENCE, G. J. AND SHEPHERD, K. W. 1981. Chromosomal location of genes controlling seed proteins in species related to wheat. Theoretical and Applied Genetics, 59, 25-31.

MACKEY, J. 1954. Neutron and X-ray experiments in wheat and a revision of the speltoid problem. Hereditas, 40 , 65-180.

MORRIS, R. AND SEARS, E. R. 1967. The cytogenetics of wheat and its relatives. In Quisenberry, K. S. and Reitz, L. P. (eds.) Wheat and wheat improvement. American Society of Agronomy, pp. 19-87.

NARANJO, T. 1982. Preferential occurrence of wheat-rye meiotic pairing between chromosomes of homoeologous group 1 . Theoretical and Applied Genetics, 63, 219-225.

PAYNE, P. I. AND LAWRENCE, G. J. 1983. Catalogue of alleles for the complex loci, Glu-A1, Glu-B1 and Glu-D1 which code for high-molecular-weight subunits of glutenin in hexaploid wheat. Cereal Research Communications, 11, 2935.

PAYNE, P. I., HOLT, L. M. AND LAWRENCE, G. J. 1983. Detection of a novel high molecular weight subunit of glutenin in some Japanese hexaploid wheats. Journal of Cereal Science, $1,3-8$.

PAYNE, P. I., HOLT, L. M., LAWRENCE, G. J. AND LAW, C. N. 1982. The genetics of gliadin and glutenin, the major storage proteins of the wheat endosperm. Qualities Plautenum. Plant Foods for Human Nutrition, 31, 229-241.

RILEY, R. AND CHAPMAN, V. 1958. Genetic control of the cytologically diploid behaviour of hexaploid wheat. Nature, 182, 713-715.

RILEY, R. AND KIMBER, G. 1966. The transfer of alien genetic variation to wheat. Annual Report of the Plant Breeding Institute Cambridge 1964-65, 6-36.
RILEY, R., CHAPMAN, V. AND JOHNSON, R. 1968. The incorporation of alien disease resistance in wheat by interference with the regulation of meiotic chromosome synapsis. Genetical Research (Cambridge), 12, 199-219.

SEARS, E. R. 1954. The aneuploids of common wheat. Bulletin of the Missouri Agricultural Experimental Station 572, 58.

SEARS, E. R. 1977. An induced mutant with homoeologous pairing in common wheat Canadian Journal of Genetics and Cytology, 19, 585-593.

SEARS, E. R. AND OKAMOTO, M. 1958. Intergenomic chromosome relationships in hexaploid wheat. Proceedings of the 10 th International Congress of Genetics (Montreal) vol. 2, 258-259.

SHEPHERD, K. W. 1973. Homoeology of wheat and alien chromosomes controlling endosperm protein phenotypes. In Sears, E. R. and Sears, L. M. S. (eds.). Proceedings of the 4th International Wheat Genetics Symposium (Columbia, Missouri) pp. 745-760.

SINGH, N. K. AND SHEPHERD, K. W. 1984. Mapping of the genes controlling high molecular-weight glutelin subunits of rye on the long arm of chromosome $1 \mathrm{R}$. Genetical Research (Cambridge), 44, 117-123.

SINGH, N. K. AND SHEPHERD, K. W. 1985. The structure and genetic control of a new class of disulphide-linked proteins in wheat endosperm. Theoretical and Applied Genetics, 71, 79-92.

STINISSEN, H. M., PEUMANS, W. J., LAW, C. N. AND PAYNE, P. I. 1983. Control of lectins in Triticum aestivum and Aegilops umbellulata by homoeologous group 1 chromosomes. Theoretical and Applied Genetics, 67, 53-58.

TSUNEWAKI, K. 1963. The transmission of the monosomic condition in a wheat variety Chinese Spring, II. A critical analysis of nine year records. Japanese Journal of Genetics, $38,270-281$.

VALKOUN, J., HAMMER, K., KUČEROVÁ, D. AND BARTOŠ, P. 1985. Disease resistance in the genus Aegilops L.-stem rust, leaf rust, stripe rust, and powdery mildew. Kulturpflanze, $35,133-153$. 